I Université Paris Nanterre, Départment de sociologie, Nanterre,

\title{
FOUCAULT AND BOURDIEU: TO EACH HIS OWN NEOLIBERALISM?
}

The following article discusses Foucault's and Bourdieu's handling of neoliberalism, and the extent to which the two authors "agreed" in their analyses. The answer is not altogether obvious, since the authors consider different periods from different perspectives. Rather than proposing a sociology of neoliberalism like Bourdieu, at the end of the I97os Foucault aimed to write a history of neoliberalism in the context of a wider history of governmentality. He also devoted the lectures he gave at the Collège de France in 1978 and 1979 entitled Security, Territory, Population and particularly The Birth of Biopolitics to the subject. Bourdieu openly attacked the utopia in mainstream economic science in the I990s, which in his eyes had come to serve as the ideological matrix renewing the forms of domination. The fact that the two authors did not come to neoliberalism at the same time or from the same perspective does not detract from the interest in examining each of their individual claims, provided we do not seek to place them in opposition, as a certain "zeitgeist" may invite us to.

Sometimes while claiming to uphold Bourdieu's arguments, sociologists, historians, and philosophers have aimed to put Foucault's analyses of neoliberalism on trial by placing the two authors in opposition, and in doing so, have manufactured a non-existent controversy. Such a task involves flattening the scope of the authors' analyses and homogenizing their points of view in order to insert them rather insidiously into our current political landscape as though they were both contemporaries to the full development of the neoliberal phe- 
nomenon. While Bourdieu would have been critical of neoliberalism, Foucault would have sympathized with it, with some critics claiming he was one of the actors behind the French intelligentsia's significant shift to the right at the end of the rg7os and in the rg8os. This is in fact evidence of a particularly academic desire to homogenize that which is not homogenous, erasing contexts in order to lump together theoretical approaches, political intentions, and scientific disciplines in order to reconcile them or, as is the case here, render them irreconcilable. Instead of resorting to the use of such questionable methods, I wish to recontextualize the two authors' approaches, as this is the only way to evaluate the scope of their respective analyses, and to eschew this particular brand of "postmortem" account settling.

Bourdieu and Foucault did not in fact have the last word on neoliberalism, which is constantly evolving and unfolding, rendering the real interest that of the respective fertility of their analyses. For authors concerned as they were with social and political transformations, nothing would have been undoubtedly stranger to them than the fixing of a doctrine to which observations made in the social and political reality must be manipulated to fit, regardless of the cost.

\section{DIFFERENCE IN ERAS}

While Bourdieu is concerned with neoliberalism's main coming of age at the end of the I 980 s and throughout the I99os, Foucault demonstrates great foresight in his detection of the phenomenon by focusing on its earliest expressions. The revelation of a clear discontinuity in the political practices of the I97os had not yet been emphasized in the intellectual and political milieux, and almost nobody had seriously considered the renewal of liberal ideas in certain spheres. The great oppositions to have structured the reading of the political and socioeconomic field were still markedly classical: left/right, bourgeoisie/working class, state/society, capitalism/socialism, and totalitarianism/democracy, and it was precisely the sweeping nature of such categories that Foucault's analyses sought to evade in order to grasp at an insidious, more "grating" transformation, as he defines it, involving the art of government.

Bourdieu's sociology of neoliberalism developed under an extremely different set of circumstances, taking shape a decade later than Foucault's, during a time when the effects of neoliberal politics had come to inform the world's immediate realities, particularly those concerning labor, public services, housing, and cities. This strand of sociology therefore focuses more on the social effects of neoliberalism, as demonstrated by Bourdieu's I 993 publication The weight of the world. Neoliberalism's sociological construction is based on its objectifiable effects, according to a method that traces the causes from the effects. ${ }^{\text {I }}$

Such a chronological difference does not, however, completely account for Bourdieu's lack of interest in Foucault's analyses, which leads us back to the 
broader question of the mutual ignorance shown by the authors, except at several critical moments, at least in their works. It is as though the "masters" of the intellectual field neither engaged with one another nor cited each other's work, pursuing their arguments with a feigned or genuine indifference, which was in any case also applicable to other academics' ongoing research. Although Bourdieu only really began to address neoliberalism at the end of the I 980 , he rarely alluded to Foucault's courses at the Collège de France, making no mention of the work being developed in Italy, England, or in the United States based on Foucault's courses, particularly in the field of studies on governmentality. For over 20 years, a notable silence was therefore maintained from Bourdieu's side on Foucault's analyses of liberalism and neoliberalism, despite Bourdieu's growing focus on neoliberalism as one of his main objects of study and political targets, with this culminating in his emergence as the "anti-neoliberal intellectual par excellence" after the wave of general strikes in France in I995. It may be said that one of the objective obstacles to a knowledge of Foucault's work was the publication of his courses on neoliberalism (taught in I978 and 1979) as late as 2004, some two years after Bourdieu's death. However, it must not be forgotten that Foucault assisted in Bourdieu's enrollment in the Collège de France in I982, and that Bourdieu had ample access to the lecture summaries. It is thus difficult to believe that he knew absolutely nothing of the two years of Foucault's lectures focusing on an intellectual and political subject which came to be of central interest to him. ${ }^{2}$

The intellectual and political reception of the two authors' analyses was also rather staggered in time, representing a somewhat curious phenomenon of intellectual and political life. With The weight of the world in I993, through his support of the I 995 strikes and other social movements to have followed the strikes (such as those representing undocumented migrants, the homeless, and the unemployed), and, thanks to his direct involvement in the creation of tools of political intervention such as the small collection Reasons to act, Bourdieu came to embody the intellectual critique of neoliberalism. His analysis of neoliberalism encroached on that of a militant condemnation, seemingly amplifying a set of widespread critical views against "liberal" or "neoliberal" reforms (with the term used in the rg9os yet to be fixed). Such a "defining political moment" extended until 2005, constituting a kind of "critical common sense" which viewed neoliberalism as a form of "ultraliberalism" or a dangerous "utopia". The resounding success of his analyses was, however, dampened by the emergence of certain limitations, particularly in terms of organization, meaning the articulation between critical researchers, the social movement, and the unions that Bourdieu hoped for failed to truly materialize.

The fate of Foucault's analyses on neoliberalism is markedly different in this respect, with such analyses conspicuously absent from public debate in France until the publication of the I978 and I979 lectures series in 2004. Al- 
though no longer considered an important resource for an understanding of events post ig8os and I99os, if Foucault remains a renowned and frequently quoted intellectual, it is thanks to his status as somewhat of a "classic". His works are better received in universities, with the number of conferences, books, and new publications on his work growing steadily in the I980s and I990s. He was also celebrated as never before upon the twentieth anniversary of his death in 2004, ushering in a new period in the second half of the 2000s. The publication of his lectures, their influence, and the great public debate in France on the European Constitutional Treaty in 2005, as well as a series of publications that placed his analyses back in the limelight, have served to transform his reputation, which will also come to affect the approach to neoliberalism in years to come, leading to a bona fide "foucauldization" of the critical approach to neoliberalism, a statement that will undoubtedly irritate some.

The lack of an overlap between the two authors' approaches to neoliberalism is not only a question of chronological time, but also a question of the "theoretical time" each belonged to, with "theoretical time" referring to the way in which the problem of neoliberalism is tied into their respective bodies of research. With The Birth of Biopolitics, neoliberalism makes a somewhat sudden and short-lived appearance on Foucault's dissection table, with the author only dedicating some seven lectures to it, with five on German ordoliberalism and two on American neoliberalism (particularly Gary Becker). Taking a further step back also demonstrates just how quickly the subject of neoliberalism came to Foucault's attention. In just two years of lectures, Foucault strides through a long history of governmentality, outlining the pastoral model used since antiquity and the factors behind its modern-day crisis, also considering the national raison d'État, biopolitics, and liberalism in its newest forms, producing an exploratory and experimental body of work, leading him quickly from one form of power to another.

Bourdieu's "timeframe" could not have been more different. Instead of a rapid encounter with the subject of neoliberalism, the phenomenon adds a complex nuance to his work, prompting a slow, almost unacknowledged realignment in his sociology that is in marked contrast to Foucault's sudden shift. In a little over Io years, from the end of the I980s to his death, his gradual development of the neoliberal phenomenon is evident from his research into a range of subjects including economics, the media, elite schools and state bodies, labor, and the housing market, etc., pointing us to another difference, which is that of the authors' theoretical styles.

\section{DIFFERENCE IN THEORETICAL STYLES}

For Foucault, research is not so much the application of a previously established frame of reference, but rather a continual transformation of the concepts and their associated relationships, meaning that instead of applying patterns to 
the "terrains", he instead produces new concepts while traversing new territories. Foucault thus approaches neoliberalism in an essentially creative style, according to a research method in which his analyses are highly unstable. The reader is repeatedly struck by the constant eruption of concepts that the author transforms as quickly as he abandons, with such decisive movements allowing him to make rapid shifts, in what may be described as rather daring meandering historical overviews.

Juxtaposed to Foucault's slippery transformations is Bourdieu's controlled transposition of his concepts, with the latter's style of work wholly different, applying a relatively stabilized conceptual framework to various subjects or fields with only the most minor of variations. Whether discussing the literary field, the political field, or the economic field, the reader is always on familiar ground with Bourdieu and rarely feels disoriented in terms of the author's style, phrasing, grammar, and syntax. The approach is more methodical than creative, implementing a highly elaborate conceptual system. In his handling of neoliberalism, Bourdieu reutilizes concepts already present in his works revised for this new territory, also establishing bold links between the "generative schemes" of his general sociology. It is remarkable to note how Bourdieu analyzes neoliberalism by mobilizing conceptual series to have emerged within other contexts of analysis, with terms such as "field", "habitus", "capital", "structural determinants", and "struggles", etc., the reassuring hallmarks of a system. ${ }^{3}$

Such a difference in style naturally corresponds to a more fundamental opposition concerning the treatment of history. Foucault departs from the theory that there are great discontinuities between historical periods that are distinguished by singular forms of power and structures of knowledge, while Bourdieu assumes that symbolic forms and social structures are inherently inert and only subject to gradual shifts. Therefore if Bourdieu comes to employ the typically Foucauldian formula of "transcendental historical", it is only to emphasize the persistence of old categories which continue to act subliminally on the present, according to the formula borrowed from Durkheim, whereby "history is the unconscious" (Bourdieu, 2013: 78). In short, Bourdieu's interest in history lies in the way in which objective and subjective structures become altered while enduring over time, and despite accusing Foucault and others of hard structuralism, he is actually the most faithful to the structuralist program, even in his efforts to incorporate the concept of historicity. With that said, if "events" exist, they must always be understood within a system of relations (between fields, between habitus and fields, and between forms of capital, etc.). Foucault (200I: I44-I45), on the other hand, emphasizes the emergence of events, associated ruptures, and discontinuities, declaring "it must be admitted that structuralism serves as the most systematic effort to evade not only ethnology but also a series of other sciences, and even the entire concept of an event, at the limits of history itself. I don't know anyone more anti-struc- 
turalist than I am". Such a difference in theoretical bases stems from two approaches which are difficult to reconcile within the analyses made of neoliberalism, as while one considers it an "event" in itself, the other considers it a "restoration".

\section{DIFFERENCE IN CRITICAL STRATEGIES}

For Foucault, intellectuals are defined by their criticism of all of the various types of power. Liberalism is, however, also a critical approach to power, constituting an external critique on behalf of fundamental rights and/or an internal critique in terms of effects and their utility. The relationship between liberalism as a critique of power and intellectuals' critical function is both delicate and problematic. Foucault's analysis of liberalism does not suggest that he is a "liberal" himself, defining it as he does as a power which adopts or claims to adopt a critical approach, even monopolizing the criticism of the governed. For this reason, it is perhaps shrewder than any other kind, due to its imposition of the modes of government by means of a conceded and controlled liberty that upholds its position of power. This is the crux of Foucault's analysis, which rather than being apologetic, instead seeks to understand the specific nature of liberalism. Such an analysis of governmental forms must be compared to the multiple times the author explains that all the signs suggest that socialism has failed and that something else must be invented, with "inventing something else" referring not so much to adhering to the neoliberal project, but rather inventing a new alternative and unprecedented mode of government. And who might be responsible for such an invention? We can suppose that, in Foucault's eyes, the movements born in the I970s (such as gay rights' movements, feminist movements, counter-cultural movements, and artistic movements, etc.) would be well positioned to play such a historic role.

Bourdieu's critical strategy is somewhat different. It is not that he does not attribute importance to symbolic and political inventions, or to the new forms of organization or action, but rather that he seeks an alliance between intellectuals whose autonomy is threatened by economic domination and the members of the working or middle classes subject to rising poverty and precariousness. Such an alliance calls for the invention of a new kind of intellectual - that of "the critical collective intellectual" - organized in a new, nonpartisan fashion and that would constitute a new body of struggle within the social movement. Bourdieu's intervention is therefore not only aimed at supporting specific demands and accompanying a movement from the outside, but is also intended to be direct and systematic, producing effects within the social and trade union-led movement. Bourdieu calls for a shift in the forms and geographies of action, in an approach which was not well received at the time by many actors in the social movement who viewed it as a form of interference, partly accounting for the short-term failure of the author's projects. His aim 
was to redefine relations between researchers and militants and between the social sciences and the social movement in order to mobilize scientific capital through action in the most direct way possible. Bourdieu's strategy implied that the social movement, for its part, should then make the most of the gains made by social sciences, in order to become more politically effective, with the social sciences locating allies within the social movement and the unions in the defense of their scientific autonomy. It was therefore a matter of relying on the social movement in order to stem economic imperialism, which was helping shape a veritable utopia thanks to neoliberal politics implemented from the I980s onwards. In short, sociology and the social movement shared the same enemy from the moment the abstract economic model of the homo economicus was configured as the blueprint for society and for human beings (Bourdieu, I998: I08-II9).

\section{DIFFERENCE IN REFERENCES AND DEFINITIONS}

Bourdieu and Foucault's versions of neoliberalism are theoretically constructed by means of different authors and corpora. For Bourdieu, neoliberalism is mainly taught as dogma in schools of power, constituting an economic belief in the Walrasian general equilibrium, and a myth or utopia with performative effects. The "pure mathematical fiction" inherent to neoclassical economic science is at the heart of neoliberalism, with government neoliberal policies aiming to make reality conform to the pure and perfect order of theory, with such a theory's supposedly scientific basis lending neoliberalism its social authority, despite its actual reliance on a utopia. Neoliberalism is therefore a pseudo-science founded on "the Walrasian myth of pure theory" helping "depoliticize" politics, thanks to its symbolic effectiveness (Bourdieu, 200I: 57). Neoliberalism is above all an allegedly scientific theory that belongs to the past of economic thought. According to Bourdieu, criticizing economic doctrines is based on the identification of a double misunderstanding, and that is that of a theoretician who places his own abstract schemes in the heads of social agents, and that of the social agent who misunderstands the historical and social conditions that have made him do what he does and become what he is. Sociological criticism must attempt to establish the link of truth between the abstract schema of rational action and the capitalist habitus by revealing the "social foundations of economic action", to use the title of a lecture series given by Bourdieu at the Collège de France in I 992-I 993. Pseudoscience must be criticized by a better founded and more realistic social science, that is, in a word, truer.

For Foucault, neoliberal theories are neither true nor false; with the most important factor their normative capacity to inform policies that make individuals act in a predictable and favorable fashion, that is to say, within a specific regime of inducements. Neoliberalism primarily finds its inspiration in German ordoliberalism and within the theory of human capital, which aims to 
articulate economic subjects within a new mode of government by means of environment variables, according to highly specific devices such as negative tax or interventions into the supply and demand of drugs. Neoliberalism should not be confused with a kind of "archeo-liberalism", or a return to Smith or Walras, with Foucault rather aiming to emphasize its novelty. The importance of the legal-political framework, the means of controlling conduct through competition-based inducements, and the widespread use of the company model did not exist as such in the old liberalism. Neoliberalism is not just the application of a scientific theory in the political domain; it is a mode of power, and a conduite des conduites [conduct of conducts], which is not the same thing.

The two authors' approaches are therefore heterogeneous, and could be crudely described as methodologically "positive" in Foucault's case and methodologically "negative" in Bourdieu's case, with the former epistemologically based on a "political history of the truth" and the latter concerning a struggle within the social sciences. Foucault (2004: 275 ff.) views this as constituting a fundamental rupture in the concept of man, due, in his opinion, to English empiricism, and serving as a key element in the new art of liberal and consequently neoliberal governing, with Locke, Hume, and Bentham its great founders. His concern is with the procedures and techniques that facilitate a kind of acting on actions on behalf of a certain truth about man and society. Bourdieu, on the other hand, sees a theoretical error engrained in the heart of economic science, based on an ill-founded abstraction that has been transformed into a political project for global domination by economic and political oligarchies, with the essential problem that of truth in the social sciences. This element of error and illusion is, however, not enough to account for neoliberalism's sheer strength. As neoliberalism is derived from an economic habitus stemming from practices, two different readings emerge, with Foucault's interest lying in devices and their effects and Bourdieu's in devices and their conditions.

Such a difference in the corpus of reference also has significant political implications. At first glance, Bourdieu's polemical texts seem compatible with a discourse rather widespread among the left, particularly post I995, and at the heart of the alter-globalization movement, particularly in terms of international network Attac founded in 1998. According to this anti-neoliberalism counter-doxa, neoliberalism is a blend of utopianism, scientism, naturalism, and nostalgia, and is therefore not that new at all, serving as a "conservative revolution", which aims to return to the policies championed by Adam Smith. Bourdieu's writings therefore seem to give credence to the extremely widespread idea that "neoliberalism" is nothing more than a "social-Darwinian" apology for "savage capitalism", which thus refuses any form of rule other than that of the self-regulating market and rejects any form of state intervention. Neoliberalism is essentially viewed from a negative angle, as a kind of political logic which "defeats", “destroys", and "dismantles". Such a negative perspective 
of the neoliberalism implemented by the upper administration could easily be reconciled with the Keynesian or Marxist interpretations which consider speculation, or more specifically capital, as an autonomous power which requires nothing more than to be free from political obstacles. On a political level, such a critique calls upon the state's defensive role as an organizer of public services, seen as the last bulwark against the rampant markets. A national popular form of sovereignty may accordingly be legitimized, even if Bourdieu (I998: $66 \mathrm{ff}$.) clearly made a stand for a new brand of internationalism.

The extremely late publication of The Birth of Biopolitics produced a veritable rupture in this anti-neoliberalism doxa by highlighting the active role of the state and its governmentalization, as well as the targeting of subjectivities, and particularly the evolution of the concept of the limits placed on government action by the market, which was characteristic of classical liberal naturalism, to that of the a priori unlimited extension of the logic of the market as promoted by government action. Foucault's contribution may be summarized as follows: although the anti-neoliberalism doxa interprets the policies implemented as a tool for destroying the rules and dismantling institutions, as well as liberating the forces springing from capital and finance, he underlines "the positivity of power", emphasizing the work of building institutions and disseminating neoliberal norms. He does not so much stress what the neoliberal state no longer does, but rather what it does to society and what it does to itself.

\section{INTERSECTIONS}

Leaving their differences aside, what intersections may be identified in the two authors' analyses? Do they share anything in common? In actual fact, one sphere in which they intersect is that of the historicity of the economic man. Neoliberalism represents a moment of acceleration on economic man's path to self-realization, by means of mechanisms of competition and punishment that are increasingly easier to identify. This is what Bourdieu (I998: I09) means when he states that "this initially desocialized and dehistoricized 'theory', has, now more than ever, the means to make itself true, and empirically verifiable". Another instance of common ground between the authors is their shared challenging of Marxist theories. The two analyses make similar efforts to disassociate themselves from ossified Marxism, with their main point of agreement and theoretical site of convergence on the "construction of the capitalist economy", which not only supposes the removal of brakes, hindrances and rules, but also the construction of institutions, norms, laws, habitus, and subjectivities. On this point, Foucault is noticeably more coherent than Bourdieu, who sometimes gives the impression in his more militant remarks that the destructive logic of neoliberalism is the only one that matters. Theoretically speaking, if the two authors may be said to agree on anything, it is in their mutual and relatively explicit abandonment of the idea that capitalism is an autonomous movement 
from which the superstructures reflecting the economic base are constructed. The dominance of capitalist rationality is not imposed merely by the expansive dynamism of capital and its colonizing of the entire social space by means of commodification. Bureaucratic leverage and political action are also required. Neoliberalism is the work of the state, which does not "resign" as Bourdieu awkwardly suggests, but instead becomes transformed into the most effective agent of the societies' neoliberal mutation.

\section{ARTICULATIONS}

Foucault and Bourdieu do not discuss the same thing at the same time, nor do they represent the same political considerations or speak with the same theoretical intentions. The difference in their treatment of neoliberalism produces two "objects", which, although not totally distinct, do not completely overlap.

The question at hand is not only that of identifying each author's research legacy or what may be extracted from their respective analyses, but what may be drawn from the relations between the two different approaches. Nothing is to stop us from articulating such relations, however to do so we must not treat the analyses as closed theoretical bodies that should be treated en masse and dogmatically repeated, but as tools at our disposal for reflecting on what has gone on in the world since the I970s and what continues to go on at an even more accelerated pace today.

Foucault's and Bourdieu's works have both proved fruitful, enriching our knowledge of the varied, long-lasting, and profound consequences of neoliberalism. In order to move beyond a purely exegetical operation, however, we must expand the field of reflection and correct affirmations made by each of the authors on previous stages of neoliberalism or based on invalidated assumptions. To expand on Foucault and Bourdieu's works, we must also learn to extract their most valuable reflections, regarding modern-day neoliberal strategies in full awareness of the social and economic forces to have driven them, for example. A sociology of oligarchies facilitating an analysis of the "field of power" is essential in this respect. We must also not assume, like some Marxists, that such strategies are the mere result of political decisions made by a class already to have been installed, retaliating against past compromises. Rather, it is important to realize that neoliberal rationality is not just produced by the existing classes but also contributes by means of its implementation of a reconfiguration of oligarchies and working-class groups. Such a concrete articulation cannot be made without addressing the all too unilateral viewpoints expressed by each of the authors. The task is to play the two authors off against each other, identifying what each one lacks, as Wendy Brown (2015) does for example when she demonstrates that the logic of capital or the question of democracy are unfortunately largely absent from Foucault's analyses. 
The final lesson to be taken from Foucault and Bourdieu is also perhaps as important as the content of their respective analyses. The intellectual model they embody is entirely contrary to all the forms of submission imposed on the researcher, whether openly or insidiously. In terms of the latter category is the powers' injunction to observe a strict "axiological neutrality", to the point of political indifference. This highly political injunction for depoliticizing research is internalized by certain agents at university institutions aiming toward the "professionalization" of philosophy and the social sciences, undoubtedly constituting the most perverse method in existence nowadays for sterilizing and anaesthetizing thought. Such a depoliticizing is nothing more than that which renders intellectuals "experts" at the service of "governance", that is to say, highly political beings hiding their real functions behind their technical skills. The current transformations underway at institutions of knowledge tend to forbid what Foucault and Bourdieu achieved and represented in their time, making it extremely important to defend their demands and extend their freedoms. It was Freud (2010), who, in facing the widespread refusal of his theories, realized that the problem with intellectuals in a society like ours remains that of the "autonomy of the intellectual worker".

Received on I I/29/2016 | Approved on 03/02/2017

Christian Laval is Professor of Sociology at the Université Paris Nanterre and a member of Sophiapol. His books include L'ambition sociologique: Saint-Simon, Comte, Tocqueville, Marx, Durkheim, Weber (2002), and, with Pierre Dardot, The new way of the world: on neoliberal society (2010) 


\section{NOTES}

I For an explanation of such an analysis from the effects to the causes, cf. Bourdieu (2013).

2 We can even be certain of the opposite, as in the bibliography for his lectures on the state, Bourdieu mentions the 1986 publication of an article on governmentality in Actes. Revue d'action juridique (no. 54, summer 1986).

3 For further reading on this subject, cf. Fabiani (20I6).

\section{BIBLIOGRAPHY}

Bourdieu, Pierre. (2013). Manet, une révolution symbolique. Cours au Collège de France (1998-2000). Paris: Seuil.

Bourdieu, Pierre. (200I). Contre la politique de dépolitisation. In: Contre-feux 2: pour un mouvement social européen. Paris: Raisons d'agir.

Bourdieu, Pierre. (1998). Contre-feux: propos pour servir à la résistance contre l'invasion néo-libérale. Paris: Raisons d'agir. Brown, Wendy. (2015). Undoing the demos: neoliberalism's stealth revolution. New York: Zone books.

Fabiani, Jean-Louis. (2016). Pierre Bourdieu: un structuralisme héroïque. Paris: Seuil.

Foucault, Michel. (2004). Naissance de la biopolitique. Cours au Collège de France (I978-I979). Paris: Gallimard/Seuil.

Foucault, Michel. (200I). Dits et écrits, II [I976-I978]. Paris: Quarto Gallimard.

Freud, Sigmund. [I9I4] (2010). Sur l'histoire du mouvement psychanalytique. Paris: Gallimard. 
Palavras-chave

Neoliberalismo;

Michel Foucault;

Pierre Bourdieu; campo intelectual francês; teoria social.

Keywords

Neoliberalismo;

Michel Foucault;

Pierre Bourdieu;

French intellectual field;

social theory.
FOUCAULT E BOURDIEU: A CADA UM SEU NEOLIBERALISMO?

\section{Resumo}

O artigo propõe uma comparação entre as abordagens de Michel Foucault e de Pierre Bourdieu sobre o neoliberalis mo. Em vez de considerar suas teorizações como totalmente antitéticas entre si, seja no plano teórico, seja no plano político, prefere-se aqui confrontar os dois autores a partir dos seguintes eixos analíticos: momentos de produção, estilos de teorização, estratégias críticas e referências intelectuais fundamentais. Ao final, serão propostas algumas interseções e caminhos para possíveis articulações entre as duas abordagens, bem como uma reflexão sobre o lugar do intelectual na filosofia e nas ciências sociais contemporâneas.

\section{FOUCAULT AND BOURDIEU: TO EACH HIS OWN NEOLIBERALISM?}

\section{Abstract}

The article sets out to compare the approaches of Michel Foucault and Pierre Bourdieu to neoliberalism. Rather than take their theorizations to be mutually antithetical, whether at a theoretical or a political level, here the aim is to compare and contrast the two authors through the following lines of analysis: moments of production, styles of theorization, critical strategies and fundamental intellectual reference points. The conclusion proposes a number of intersections and paths towards potential articulations between the two approaches, as well as a reflection on the place of the intellectual in the contemporary social sciences and philosophy. 